\title{
Agents with Periodontal Regenerative Potential Regulate Cell-mediated Collagen Lattice Contraction in vitro
}

\author{
R.L. MacNeil ${ }^{1 *}$, J. D ${ }^{\prime}$ Errico ${ }^{1}$, C. Strayhorn ${ }^{1}$, H. Pickrum ${ }^{2}$, and M.J. Somerman ${ }^{1,3}$ \\ ${ }^{2}$ Department of Periodontics/Prevention/Geriatrics, School of Dentistry, University of Michigan, Ann Arbor, Michigan 48109-1078; ${ }^{2}$ The \\ Procter \& Gamble Co., Cincinnati, OH; and ${ }^{3}$ Department of Pharmacology, School of Medicine, University of Michigan, Ann Arbor, Michigan \\ 48109; *to whom correspondence should be addressed
}

\begin{abstract}
A variety of pharmaceutical agents has been proposed for use in periodontal therapy to inhibit loss of alveolar bone and to promote regeneration of tissues lost to disease. The purpose of this study was to determine the effects of such agents on periodontal cell-mediated gel contraction, an in vitro process considered representative of wound contraction and remodeling in vivo. Human gingival fibroblasts were cultured in a type I collagen lattice, and contraction was quantified by means of a computer-assisted video imaging system. Cell-gel combinations were prepared with cells both pre-exposed and non-exposed to agents; non-anchored cell-gels were then incubated with agents for various time periods. Agents tested included Demecolcine (an inhibitor of cytoskeletal contraction), growth factors (i.e., TGF- $\beta 1$, PDGF, and IGF-1), and non-steroidal antiinflammatory drugs (NSAIDs) (indomethacin, ibuprofen, naproxen, and flurbiprofen). While Demecolcine inhibited gel contraction, TGF- $\beta 1(1-20 \mathrm{ng} / \mathrm{mL})$, PDGF $(100 \mathrm{ng} / \mathrm{mL})$, IGF-1 $(1000 \mathrm{ng} / \mathrm{mL})$, and [PDGF + IGF], all of which have been reported to enhance wound healing in vivo, promoted lattice contraction in this system. In contrast, NSAIDs inhibited cell-gel contraction. Ethanol, used to solubilize two specific NSAIDs, also inhibited cell proliferation and gel contractile ability, even at very low concentrations. These findings indicate that periodontal cells respond differently to various agents in vitro and may be adversely affected by alcohol. Furthermore, the results of this study suggest that the cell-lattice contraction system holds potential as a method for screening agents for positive or negative effects on cell activity.
\end{abstract}

Key words: cell culture, three-dimensional cultures, periodontics, growth factors, NSAIDs, contraction, collagen, fibroblasts, alcohol, wound healing, cytokine.

Received April 27, 1995; Accepted November 7, 1995

\section{Introduction}

There is a general agreement that periodontal tissues lost as a consequence of disease can be restored, at least in part (Aukhil et al., 1990). Such regeneration requires the formation of both mineralized and soft connective tissues. According to current evidence, these tissues are formed by cells derived from the remaining healthy portions of periodontal tissues including the periodontal ligament and/or the endosteal spaces of alveolar bone (Aukhil et al., 1990; McCulloch, 1993). To form new tissues, these progenitor cells undergo a series of important biological events which most likely include migration, attachment to a substratum, proliferation, and differentiation (MacNeil and Somerman, 1993). The recognition that these processes occur during regenerative healing has resulted in efforts to identify and develop agents capable of promoting such events.

Most research directed at evaluating agents for use in treatment of periodontal diseases typically involve higherorder animals and humans. These studies have included evaluation of agents for their ability to alter microflora (Kornman et al., 1990), to reduce attachment loss (Offenbacher et al., 1992; Heasman et al., 1993), to foster new attachment formation, and/or to induce regeneration (see review: Caffesse et al., 1993). The development of in vitro models that can be used to screen agents prior to the initiation of animal or human clinical trials will decrease cost and time of product development and may reduce the need for animal experimentation, especially in situations where screening indicates that an agent has limited utility. Importantly, reliable screening models may also increase the success rate of clinical trials.

A variety of cells, nutrients, and factors has been assembled within collagen gels, in vitro, in attempts to develop a model more closely resembling an in vivo system when compared with monolayer cell culture (Montesano and Orci, 1988; Tomasek et al., 1992; Hoffman, 1993; Huang et al., 1993). The cell-collagen gel system is based on the principle that, under normal conditions, fibroblasts suspended in a collagen matrix reduce the matrix and remodel the gel to form a tissueequivalent material. This process is considered to be 
representative of wound repair and remodeling in vivo (Bell et al., 1979; Ehrlich and White, 1983). Contraction and remodeling are regulated by cell attachment to the extracellular matrix and resulting traction force mediated by specific cellular proteins (Huang et al., 1993; Lee et al., 1993). The specific hypotheses upon which the present investigations were based are that (a) periodontal cells have the capacity to contract a collagen lattice in vitro, and (b) the contractile ability of periodontal cells will be altered by exposure to specific agents in vitro. If this model is successful, it may prove useful in screening agents for their potential use in wound healing/regenerative therapy prior to in vivo testing.

\section{Materials and methods}

\section{Cell culture}

The methods for obtaining and culturing periodontal ligament (PDLF) and gingival fibroblasts (GF) have been reported in detail (Somerman et al., 1988). All tissues were obtained by a protocol that was reviewed and approved by an institutional review board and upon informed consent of the donor. Briefly, tissues were obtained from healthy gingiva and periodontal ligaments of pre-molar teeth of five individuals undergoing tooth extraction for orthodontic reasons. When cells, growing from the explant, achieved confluency, they were transferred to $75-\mathrm{cm}^{2}$ tissue culture flasks and designated "first passage cells". Stocks of these cells, stored in liquid nitrogen, were used for the present studies. Cells were cultured in complete media [Dulbecco's Modified Eagle Medium (DMEM, Gibco BRL, Grand Island, NY) supplemented with $10 \%$ fetal bovine serum (FBS), 100 units $/ \mathrm{mL}$ penicillin, $100 \mathrm{mg} / \mathrm{mL}$ streptomycin, 1.16 $\mathrm{mg} / \mathrm{mL}$ glutamine] and incubated in a humidified atmosphere of $5 \%$ carbon dioxide- $95 \%$ air, at $37^{\circ} \mathrm{C}$. Cells were used between the 4 th and 8 th passages. Individual experiments utilized cells derived from one donor only.

\section{Pre-incubations}

In some experiments, monolayer cells were pre-incubated with various concentrations of test agents prior to incorporation of cells into the collagen matrix. In these cases, media were removed from the cultures, cells washed with Hanks' Balanced Salt Solution (HBSS), and standard media supplemented with designated concentrations of selected agents replaced for a period of $48 \mathrm{hrs}$ preceding the gel contraction experiments.

\section{Collagen gels}

The collagen used in all assays was Vitrogen 100, a pepsinsolubilized type I bovine dermal collagen dissolved in $0.012 \mathrm{~N}$ $\mathrm{HCl}$ (Celtrix Labs, Palo Alto, CA). Collagen gels were prepared by the addition of $0.65 \mathrm{~mL}$ Vitrogen, at $3 \mathrm{mg} / \mathrm{mL}$ to $0.15 \mathrm{~mL}$ distilled $\mathrm{H}_{2} \mathrm{O}, 0.10 \mathrm{~mL} 0.1 \mathrm{M} \mathrm{NaOH}$, and $0.10 \mathrm{~mL} 10 \mathrm{X}$ Minimal Essential Media (MEM, Sigma, St. Louis, MO), pH 7.4. A final concentration of $1.95 \mathrm{mg} / \mathrm{mL}$ Vitrogen was selected based on concentrations reported previously (Gullberg et al., 1990; Tingström et al., 1992) and the achievement of a gel that had uniform consistency when set.

To prepare cell-collagen gel combinations (Fig. 1), we

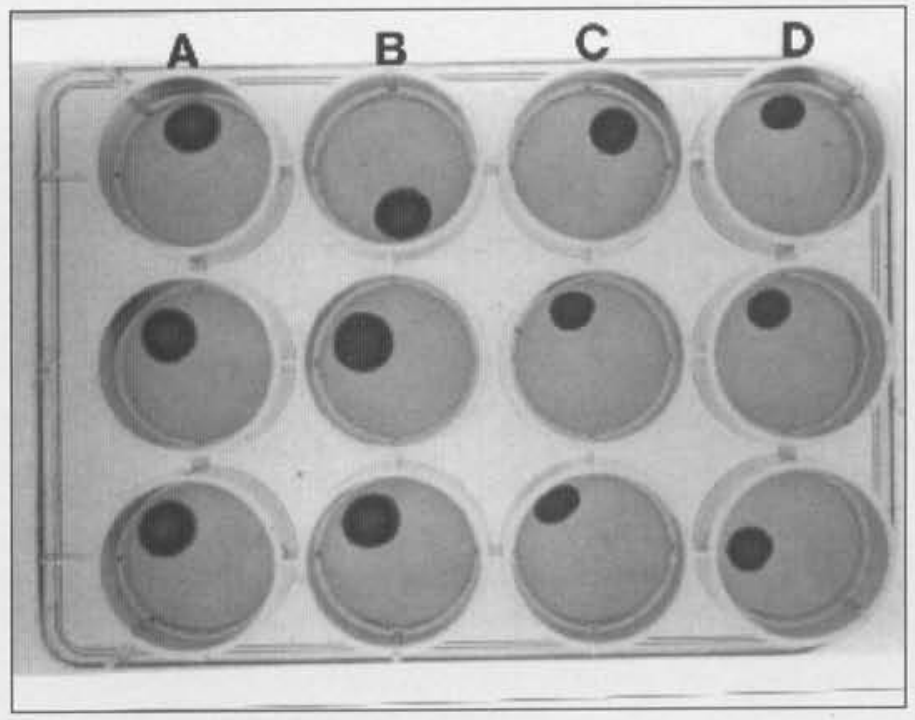

Figure 1. Non-anchored (floating) cell-gel combinations at $24 \mathrm{hrs}$. Row $\mathrm{A}=$ control; Row $\mathrm{B}=1 \mathrm{ng} \mathrm{TGF}-\beta 1 / \mathrm{mg} ;$ Row $\mathrm{C}=10 \mathrm{ng} \mathrm{TGF}-\beta 1 / \mathrm{mg}$; Row $\mathrm{D}=20 \mathrm{ng} \mathrm{TGF}-\beta 1 / \mathrm{mg}$.

washed confluent cultures of cells at passages 4 to 8 in HBSS; cells were detached by means of $0.1 \%$ trypsin in HBSS. Trypsin activity was neutralized with DMEM $+10 \%$ FBS, whereupon cells were centrifuged and re-suspended in freshly prepared soluble collagen (i.e., pre-gelation) at a concentration of $5 \times 10^{5}$ cells $/ \mathrm{mL}$. One $\mathrm{mL}$ of the cell-collagen solution (and for controls, collagen alone) was added to each of 12 -well tissue culture plates (diameter $=23 \mathrm{~mm}$ ) so as to cover the bottom of the well completely. Gels were allowed to solidify for $45 \mathrm{~min}$, at $37^{\circ} \mathrm{C}$, after which $1.0 \mathrm{~mL}$ of standard media were added. At this point, gels were gently released from the sides and bottoms of wells (Fig. 1). Plates were then placed on a shaker and incubated at $37^{\circ} \mathrm{C}, 95 \%$ air $/ 5 \% \mathrm{CO}_{2}$.

Initial gel contraction experiments were conducted with both gingiva and periodontal ligament fibroblasts, but since differences in gel contractile properties were not detected (Fig. 2), gingival fibroblasts were selected as the cell type for all subsequent experiments. All gel experiments were conducted in triplicate (three gels per treatment group). Gel area measurements were taken at specified intervals, usually from 0 to $24 \mathrm{~h}$, following the techniques described in the "Methods" section entitled "Quantification/data analysis".

\section{Cell proliferation assay}

In conjunction with the cell-gel lattice contraction assay, agents were evaluated for their effects on cell proliferation by parallel monolayer cultures. For proliferation assays, cells were seeded at $5 \times 10^{5}$ cells and allowed to adhere overnight. On the following day, cells from three dishes were counted by Coulter Counter to establish a baseline cell count. Remaining dishes received vehicle or the selected agent (see below). Cell counts were performed at various time intervals up to day seven.

This assay is essential, since it is recognized that a positive relationship exists between cell number and gel contraction, i.e., increasing cell number increases gel contraction (Bell et al., 1979). In addition, this assay allows for an indirect determination of the toxicity of agents as reflected by cell proliferation. Trypan blue 


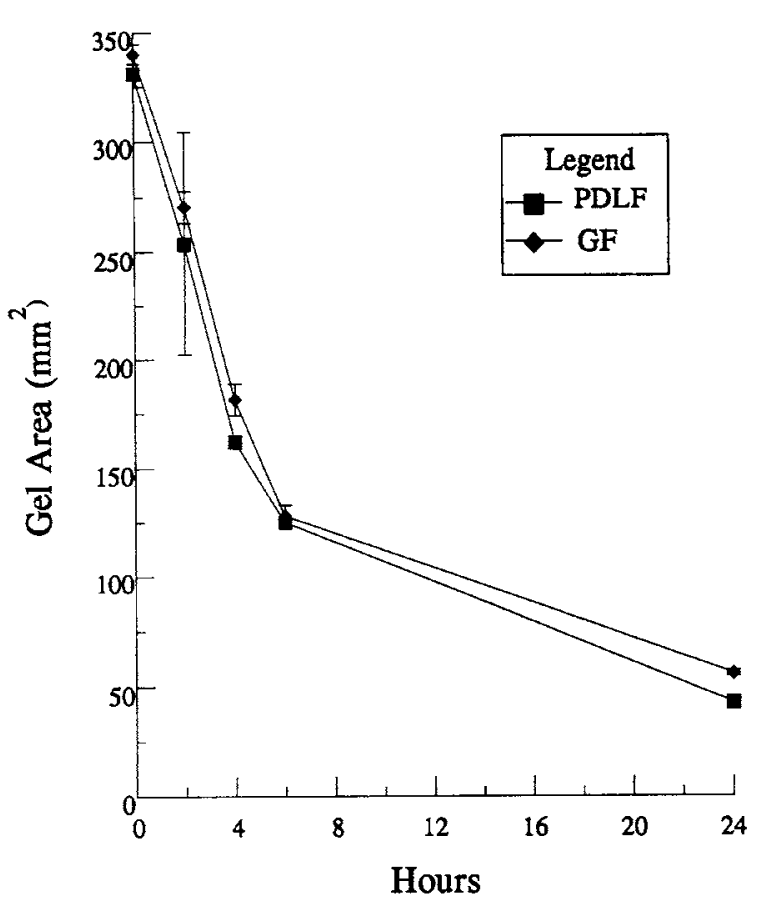

Figure 2. Comparison of gel contractile patterns for periodontal ligament (PDLF) and gingival (GF) fibroblasts. Differences were not statistically significant $(\mathrm{P}>0.01 ; \mathrm{n}=3)$.

vitality staining was also performed to determine toxicity of agents. Monolayer cultures were used, since these cultures are generally more sensitive to agents (Hoffman, 1993).

\section{Agents}

The agents used were as follows: $2 \%$ Demecolcine, a cytoskeletal inhibitor, purchased from Sigma, was prepared from a stock water base solution of $100 \mathrm{mg} / \mathrm{mL}$. Non-steroidal anti-inflammatory agents (NSAIDs) were indomethacin, ibuprofen, naproxen, and flurbiprofen (all agents were purchased from Sigma). Indomethacin and ibuprofen were first solubilized in ethanol and then diluted from a $10 \mathrm{mg} / \mathrm{mL}$ stock solution with standard media. Because of the necessity of using ethanol in the preparation of these agents, ethanol was included as a control in related cell-gel and monolayer culture experiments. Two water-soluble NSAIDs, naproxen and flurbiprofen, were prepared by dilution with media from a stock solution of $5 \mathrm{mg} / \mathrm{mL}$ sterile water.

Growth factors, platelet-derived growth factor (PDGF-AA) and insulin growth factor-I (IGF-I), were purchased from Calbiochem (San Diego, CA) and prepared from stock solutions in water of $2 \mathrm{ng} / \mathrm{mL}$ and $50 \mathrm{ng} / 100 \mathrm{~mL}$, respectively. Transforming growth factor $\beta 1$ (TGF- $\beta 1$ ), purchased from R\&D Systems (Minneapolis, MN), was prepared from a $2 \mathrm{ng} / \mathrm{mL}$ solution in $4 \mathrm{mM} \mathrm{HCL} / 1 \%$ bovine serum albumin (BSA).

\section{Quantification/data analysis}

To determine the surface area of contracting gels, we removed gels from the incubator at designated intervals and viewed them from above using a high-resolution video camera (MTI, Michigan City, IN) equipped with a micro lens and mounted on

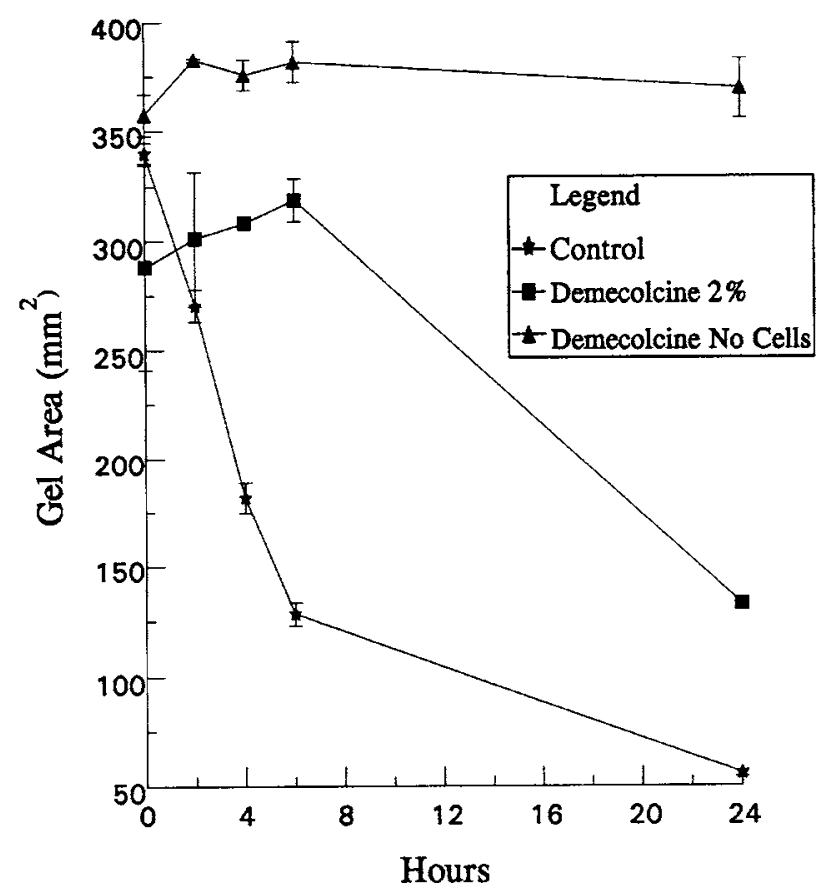

Figure 3. Effect of the cytoskeletal inhibitor Demecolcine on gingival-fibroblast-mediated gel contraction. Demecolcine significantly $(\mathrm{P} \leq 0.001 ; \mathrm{n}=3$ ) inhibited gel contraction at 4,6 , and $24 \mathrm{hrs}$, with the most profound effects observed at early timepoints. Data represent the combined results of three experiments and are represented as mean $\mathrm{mm}^{2} \pm$ standard deviation per timepoint.

a copystand. Real-time visual images were converted to captured digital images by means of a Macintosh II CI computer equipped with hardware for digital conversion and image processing (Pixel Buffer, Perceptics Corp., Nashville, TN). Processed images were displayed on a Macintosh highresolution RGB monitor with $640 \times 480$ pixel resolution and up to 256 shades of gray. Surface area measurements were conducted by means of an image processing software program, $\mathrm{NIH}$ Image 1.4.1. Final measurements were averages of three independent measurements taken on each gel at each timepoint.

Data were expressed as means \pm standard deviation. Statistical analysis was performed by one-way analysis of variance tests (ANOVA) and the Tukey-Kramer Multiple Comparisons test. Significance was determined at the $\mathrm{P} \leq 0.01$ level or greater.

\section{Results}

\section{Gingival vs. periodontal ligament fibroblasts}

Initially paired populations (i.e., cells derived from the same donor) of gingival and periodontal ligament fibroblasts were compared for gel contractile ability. As illustrated in Fig. 2, no statistically significant differences were noted between these two cell types at any timepoint. Hence, all subsequent experiments were conducted with gingival fibroblasts.

\section{Demecolcine}

To determine whether exposure of cells within the gel to agents that inhibit microtubule function would inhibit the ability of 


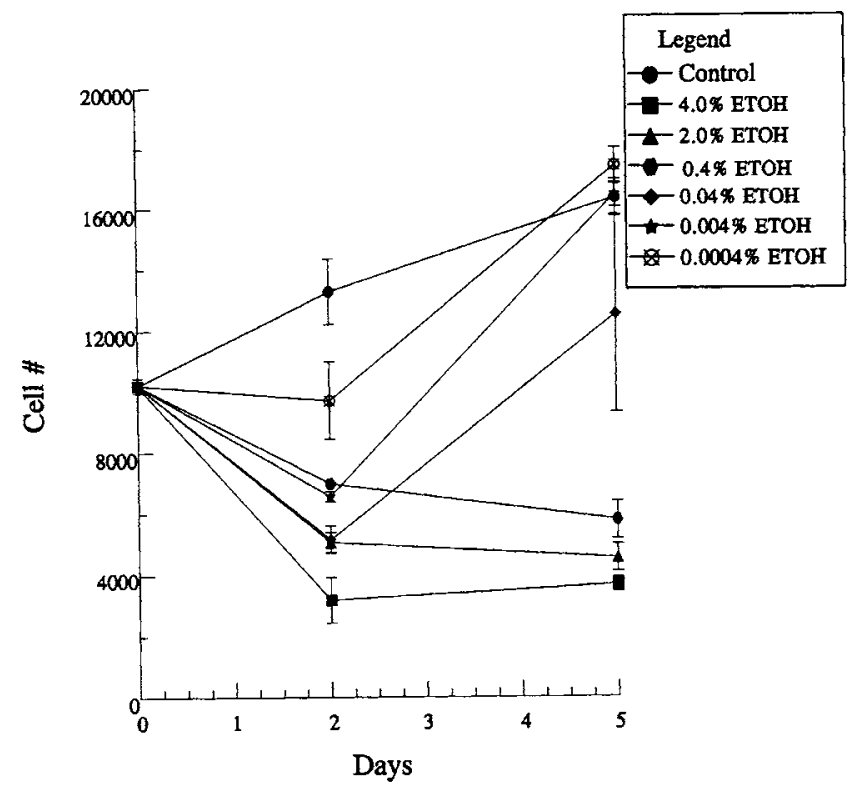

Figure 4. Effect of ethanol (ETOH) on gingival fibroblast proliferation. All concentrations of ethanol (from 0.0004 to $4.0 \%$ ) significantly $(\mathrm{P} \leq 0.001 ; \mathrm{n}=3)$ inhibited cell proliferation at day 2 of culture. Cells exposed to lower concentrations of alcohol $(<0.4 \%)$ recovered by day 5 , while higher concentrations (i.e., $0.4,2.0,4.0 \%$ ) continued to inhibit ( $\mathrm{P} \leq 0.001 ; \mathrm{n}=3$ ) cell proliferation throughout the culture period.

gingival fibroblasts to contract gels, we exposed cell-gels to Demecolcine. As shown in Fig. 3, Demecolcine inhibited cellmediated gel contraction. Cells were viable based on

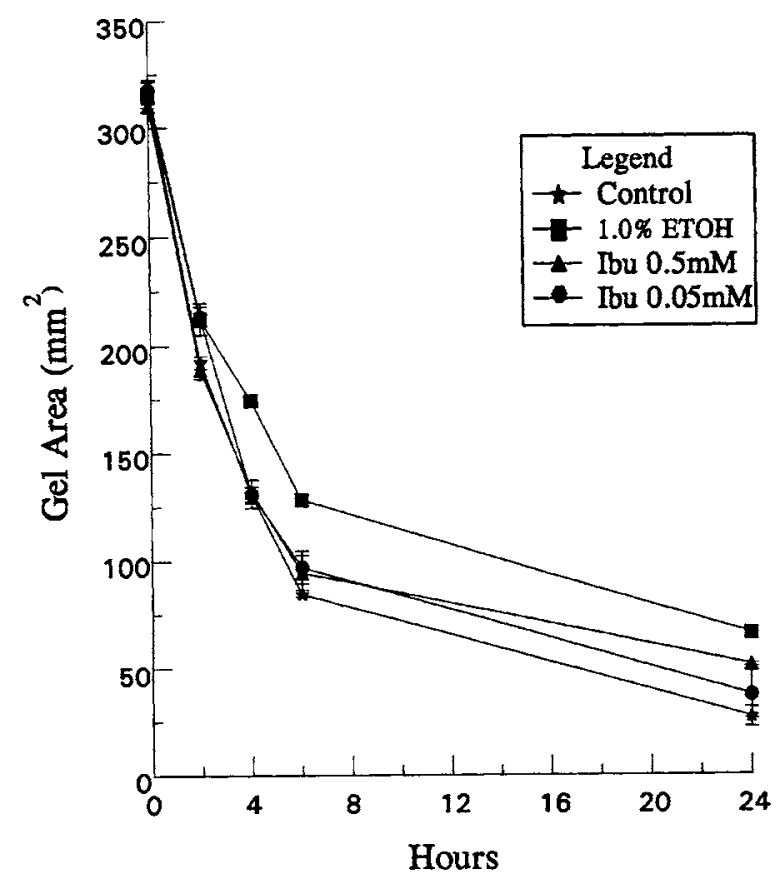

Figure 5. Effect of ibuprofen (IBU) on gel contraction. Exposure of gel cultures to $\geq 1 \%$ ethanol without naproxen significantly inhibited gel contraction up to $6 \mathrm{hr}$. Concentrations of ibuprofen achievable with $\leq 1 \%$ ethanol, i.e., $\leq 0.5 \mathrm{mM}$ ibuprofen, did not significantly influence gel contraction $(n=3)$.

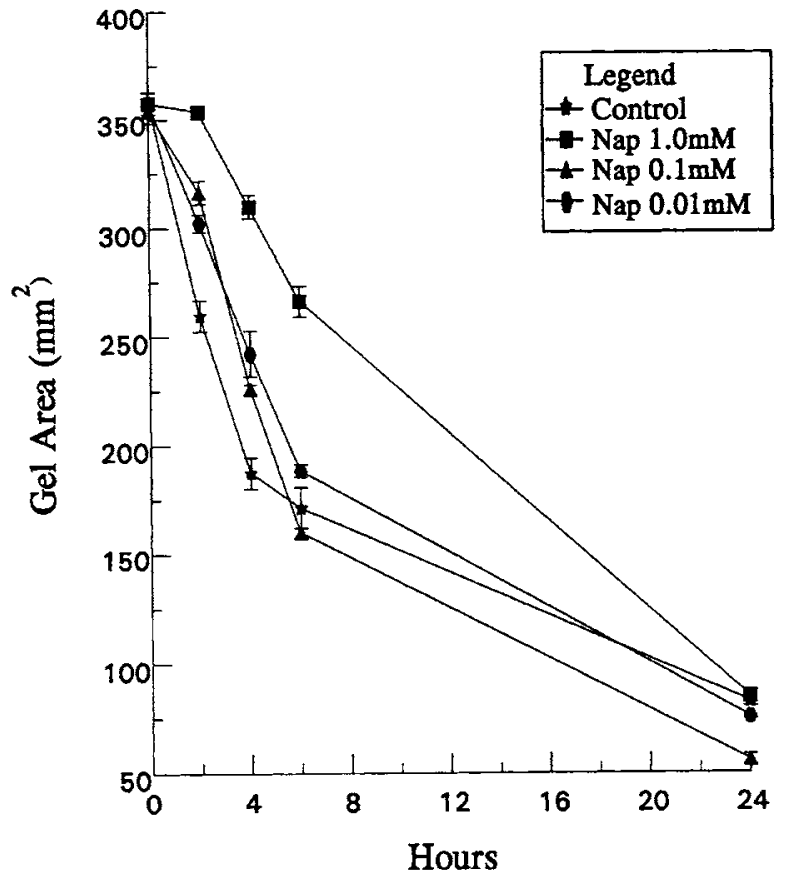

Figure 6. Effect of naproxen (NAP) on gel contraction. Pre-incubation and continued exposure of cell-gels to three concentrations of ibuprofen, a water-soluble NSAID, resulted in a significant $(\mathrm{P} \leq 0.001$; $n=3$ ) reduction in gel contraction at 2 and $4 \mathrm{hr}$. This inhibitory effect continued through $6 \mathrm{~h}$ for the highest concentration of naproxen $(1.0$ $\mathrm{mM}$ ). However, by $24 \mathrm{hr}$, all test groups had rebounded to approximate the control groups.

morphology and trypan blue exclusion assay (data not shown).

\section{NSAIDs}

First, two alcohol-soluble NSAIDs, indomethacin and ibuprofen, were evaluated for their effects on cell proliferation and cell-gel contraction. As seen in Fig. 4, alcohol alone, even at very low concentrations, i.e., $0.0004 \%$ $(0.087 \mathrm{mM})$, altered cell proliferation at early timepoints. In addition, cells exposed to ethanol at concentrations of $1.0 \%$ $(217 \mathrm{mM}$ ) or greater had reduced ability to stimulate gel contraction (Fig. 5). This apparent sensitivity of cells to low alcohol concentrations limited the concentrations of ibuprofen and indomethacin that could be used in these experiments. At concentrations of indomethacin $(0.05 \mathrm{mM}$ $0.2 \%$ alcohol) and ibuprofen $(0.05 \mathrm{mM}-0.1 \%$ alcohol), where alcohol alone had no effect on gel contraction, agents did not influence gel contraction beyond that observed with the alcohol vehicle alone.

Next, two water-soluble NSAIDs, naproxen and flurbiprofen, were tested in the cell-gel contraction system. Cells were pre-incubated with naproxen $(0.01 \mathrm{mM}-1.0 \mathrm{mM})$ or flurbiprofen $(0.01 \mathrm{mM}-1.0 \mathrm{mM})$ for $48 \mathrm{~h}$. Following this pretreatment, cells were added to the cell-gel contraction system, and media with appropriate drugs (i.e., same concentration of naproxen or flurbiprofen) were added. Naproxen at concentrations of $1.0,0.1$, and $0.01 \mathrm{mM}$ and flurbiprofen at 1.0 and $0.1 \mathrm{mM}$ significantly inhibited gel 
A

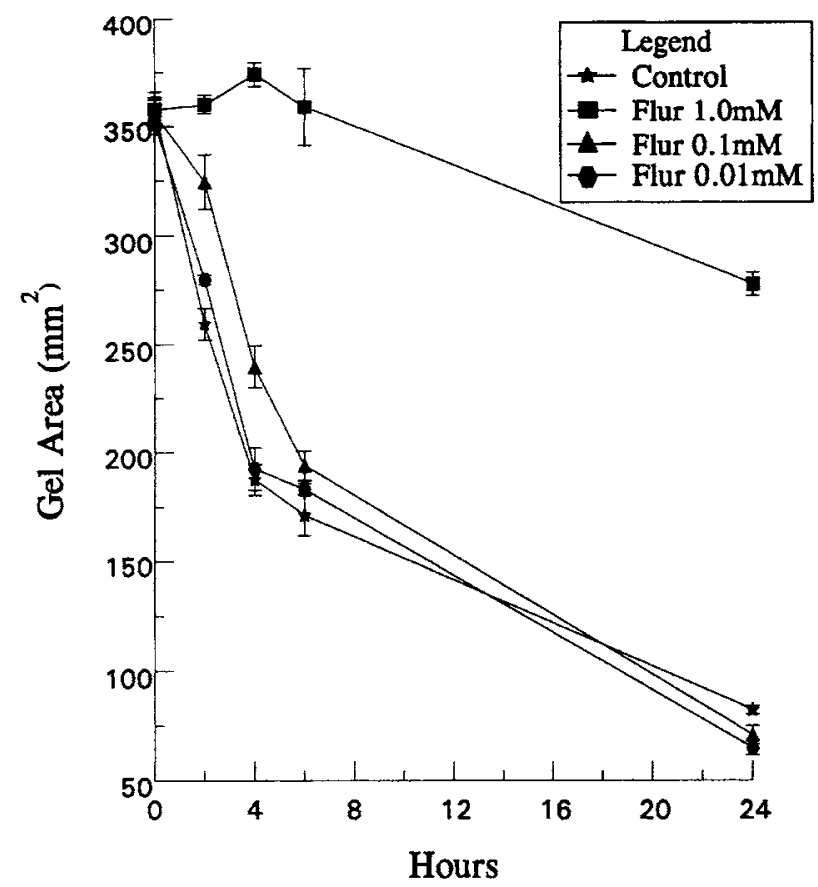

WITHOUT PRE-INCUBATION

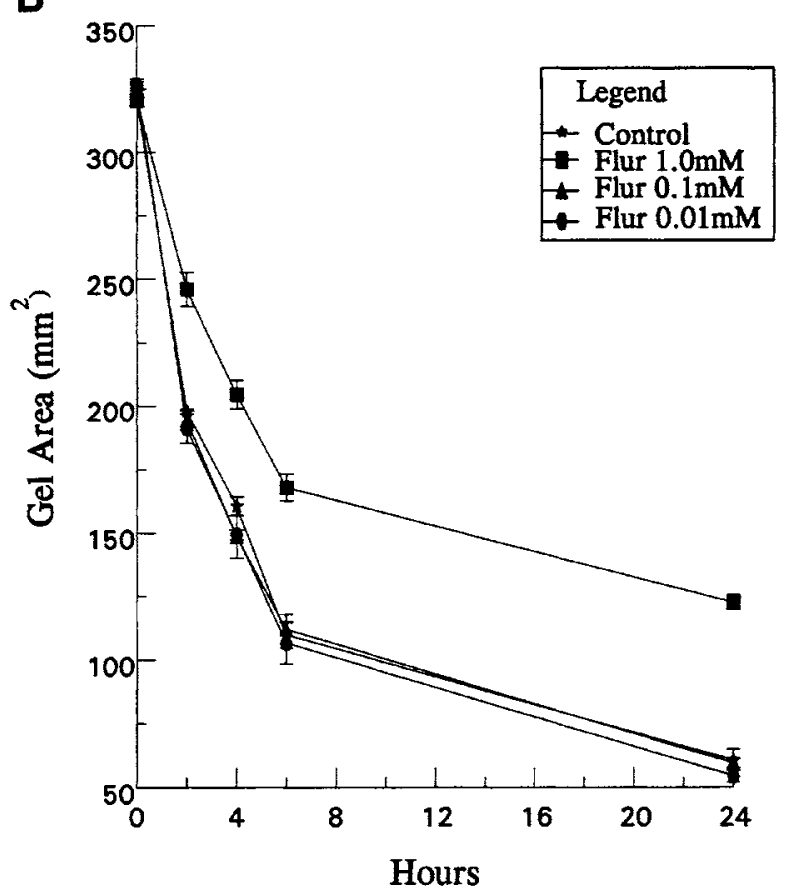

Figures 7A and 7B. Effect of pre-incubation (A) of cells on gel contraction compared with that observed when cells were not pre-incubated (B) with flurbiprofen (Flur) prior to incorporation into gels. In both cases, $1.0 \mathrm{mM}$ flurbiprofen significantly $(\mathrm{P} \leq 0.001 ; \mathrm{n}=3$ ) inhibited gel contraction at all timepoints, although pre-incubation resulted in a more dramatic and sustained effect at this particular concentration. Cellgels' pre-incubation with $0.1 \mathrm{mM}$ flurbiprofen also demonstrated a significant $(\mathrm{P}<0.001 ; n=3)$ reduction in contraction at 2 and 4 hr. No other significant differences were observed between groups.

contraction up to $4 \mathrm{~h}$, while both agents at $1.0 \mathrm{mM}$ concentration were inhibitory to $6 \mathrm{~h}$ (Figs. 6, 7A). By $24 \mathrm{~h}$, cell-gels exposed to naproxen had recovered from this initial inhibitory effect. In contrast, cells exposed to flurbiprofen were severely limited in their capacity to contract gels at all timepoints evaluated. These results were extremely reproducible, being noted in three independent experiments.

Since cells pre-incubated with flurbiprofen demonstrated a sustained inhibition of contractive ability, cell-gel contraction was further assessed with cells which were not pre-treated with this agent. In the absence of a pre-incubation phase, flurbiprofen at 1.0 $\mathrm{mM}$ had a marked inhibitory effect on cell-gel contraction (Fig. 7B); however, this effect was not as remarkable as that seen following pre-incubation of cells with the drug (Fig. 7A). To determine if flurbiprofen at dosages tested may have a cytotoxic effect, we exposed cells in monolayer cultures to flurbiprofen $(0.01 \mathrm{mM}$ to $1.0 \mathrm{mM}$ ) and monitored the proliferation rate over a seven-day period. Following short-term drug exposures comparable with those used in the cell-gel contraction assays, cell proliferation was not altered by flurbiprofen. However, by day four, cells exposed to higher concentrations of flurbiprofen (i.e., $1.0 \mathrm{mM}$ ) were growthinhibited when compared with untreated cells or cells treated with lower concentrations of flurbiprofen (Fig. 8). To determine whether these cells were still capable of proliferating, we removed flurbiprofen and cultured cells in standard media for three days. As demonstrated in
Fig. 8, gingival fibroblasts by day seven had recovered from the inhibitory effects of lower concentrations of flurbiprofen, and cell proliferation had rebounded when compared with cells exposed continuously to drug. However, cells exposed to the highest concentration of flurbiprofen $(1.0 \mathrm{mM})$ continued to show reduced proliferative activity relative to controls following three days in the absence of this agent.

\section{Growth factors}

At timepoints as early as two hours, TGF- $\beta 1$ enhanced gel contraction at doses ranging from $1-20 \mathrm{ng} / \mathrm{mL}$ (Fig. 9). IGF-1 $(1000 \mathrm{ng} / \mathrm{mL})$ and PDGF $(100 \mathrm{ng} / \mathrm{mL})$ also stimulated gel contraction, with an additive effect when cells were exposed to both in combination (Figs. 10A, 10B).

\section{Discussion}

The two major objectives of this study were to design a cellgel system where periodontal cells promoted reproducible contraction of collagen matrices and then to assess various agents with potential application in periodontal therapy for their ability to influence cell-collagen gel contraction. During development of this model system, a variety of published methods for gel preparation and measurement was assessed; these included comparison of anchored (attached) vs. nonanchored (floating) cell-gel systems (Nakagawa et al., 1989; Grinnell, 1994), evaluation of linear (ruler) measurement of contracted gels vs. scintillation counting of ${ }^{3} \mathrm{H}_{2} \mathrm{O}$-labeled gels 


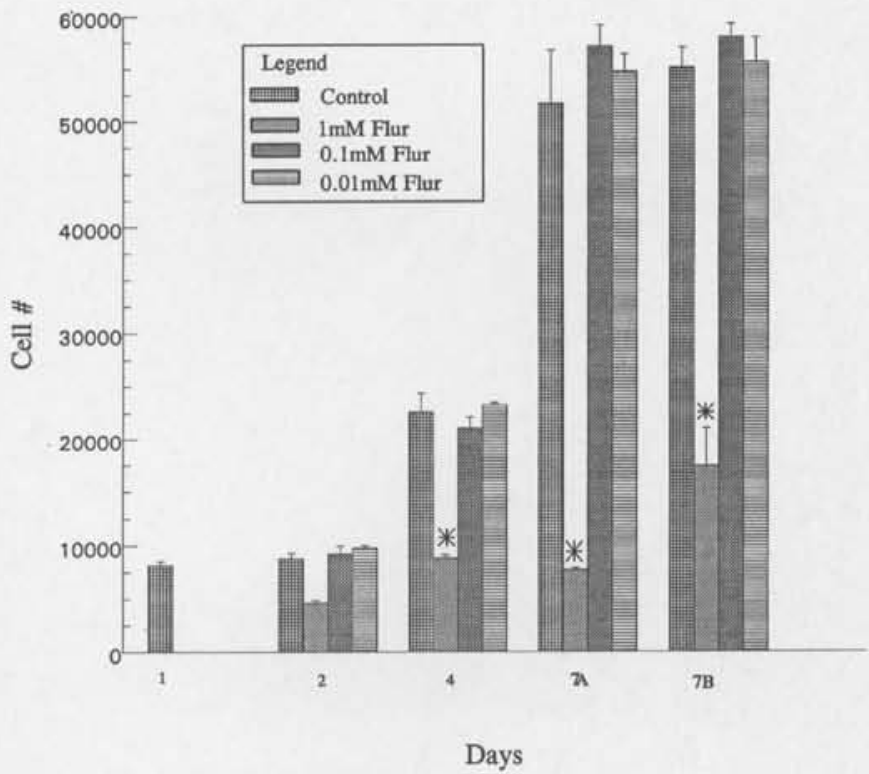

Figure 8. Effect of flurbiprofen (Flur) on gingival fibroblast proliferation and cell recovery after drug removal. Cells were exposed to flurbiprofen (from 0.01 to $1.0 \mathrm{mM}$ ) over a seven-day period. Cells exposed to $1.0 \mathrm{mM}$ flurbiprofen were growthinhibited by day four when compared with untreated cells or cells treated with lower doses of flurbiprofen. Flurbiprofen was then removed from half of the cell cultures. By day seven, gingival fibroblasts in the absence of flurbiprofen (Fig. 7B) had recovered slightly when compared with cells continuously exposed to $1.0 \mathrm{mM}$ flurbiprofen (Fig. 7A); however, proliferation was still significantly reduced $(\mathrm{P}<0.001$, denoted by $* \mathrm{n}=3$ ) relative to controls.

(Mochitate et al., 1989), and video-imaging of non-labeled gels, and comparison of gingival vs. periodontal ligament fibroblasts contractile patterns (present study). The system described here, i.e., gingival fibroblast cells cultured in nonanchored gels and measured by computer-assisted imaging, represented the most consistent and accurate method for the quantification of gel matrix contraction. Multiple replicate experiments revealed that fibroblasts derived from either human gingival connective tissue or periodontal ligament contracted gels similarly and consistently, with only minor inter-experimental variability; this contractile ability was negated by Demecolcine, a cytoskeletal inhibitor. These results are in agreement with those of previous studies which reported that various cytoskeletal antagonists inhibit cellmediated gel contraction (Kasugai and Ogura, 1993) and indicated that cells within the collagen gel were functional and responsive to exogenous agents. A particularly interesting finding was that NSAIDs and growth factors influenced gingival fibroblast-mediated gel contraction in distinctly different fashions.

Recent interest in using NSAIDs to control periodontal tissue destruction (Offenbacher et al., 1992; Heasman et al., 1993) prompted us to examine four specific NSAIDs formulations in the cell-gel system. In vivo, NSAIDs inhibit the production of mediators of inflammation and subsequent osteoclast activation by blocking the enzyme systems, i.e., eicosanoids, that convert arachidonic acid to individual metabolites, e.g., prostaglandins and leukotrienes. (The term "eicosanoids" refers to the

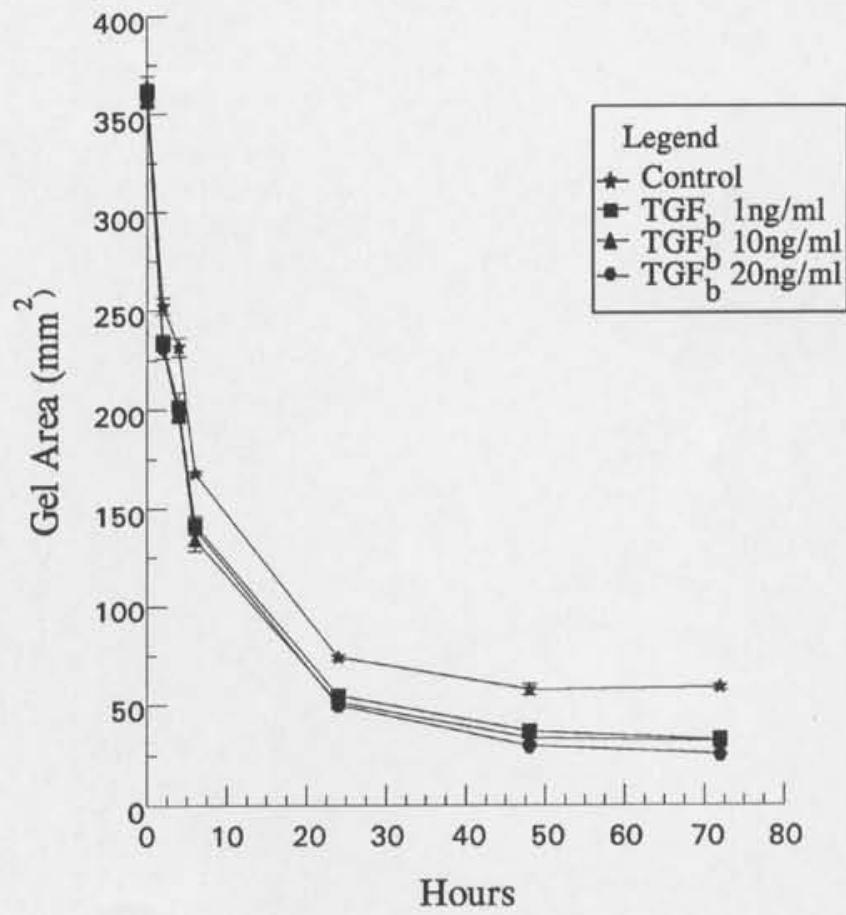

Figure 9. Effect of TGF- $\beta 1$ on gingival-fibroblast-mediated gel contraction. TGF- $\beta_{1}$ at concentrations of $1 \mathrm{ng} / \mathrm{mL}, 10 \mathrm{ng} / \mathrm{mL}$, and $20 \mathrm{ng} / \mathrm{mL}$ significantly increased gel contraction at $2 \mathrm{hr}(\mathrm{P} \leq 0.01)$ and all other timepoints $(P \leq 0.001)(n=3)$.

arachidonic acid cascade products and not to the enzyme systems involved in their production.) Our findings indicate that NSAIDs inhibit both collagen gel contraction and cell proliferation in monolayer cultures. Similar inhibitory effects of NSAIDs on cell proliferation were reported by Nguyen and Lee (1993), who demonstrated that fibroblasts exposed to dosages in the range of $10^{-1}$ to $10^{-4} \mathrm{mM}$ exhibited a decrease in proliferation. Interestingly, in this situation, the authors concluded that the antiproliferative effect of NSAIDs may prove clinically advantageous for preventing excessive scar formation in certain situations, i.e., postglaucoma filtration surgery. This is in contrast to the reported negative effects of NSAIDs on healing of duodenal ulcers, where NSAIDs are thought to inhibit the proliferation of mucosal cells (Levi et al., 1992).

While flurbiprofen was found to have an inhibitory effect on gingival fibroblast cell growth at four days of cell exposure, the inhibitory effect on cell-gel contraction was observed as early as $2 \mathrm{~h}$ (Figs. 7A, 7B). This effect cannot be attributed to cell toxicity, since gingival fibroblasts retained a normal morphology and excluded trypan blue stain during the culture periods. One explanation for this result may lie in the demonstration that arachidonic metabolites enhance gel matrix contraction by up-regulating the expression of several integrin $\alpha$-subunits (Milam et al., 1991); hence, the inhibitory effect observed with NSAIDs could be attributed to their anti-cyclooxygenase properties.

In contrast to NSAIDs, growth factors tested enhanced the ability of gingival fibroblasts to contract collagen gels. A similar profile of gel contraction was observed with TGF$\beta 1$, PDGF, and IGF-1, while PDGF and IGF-1 in 


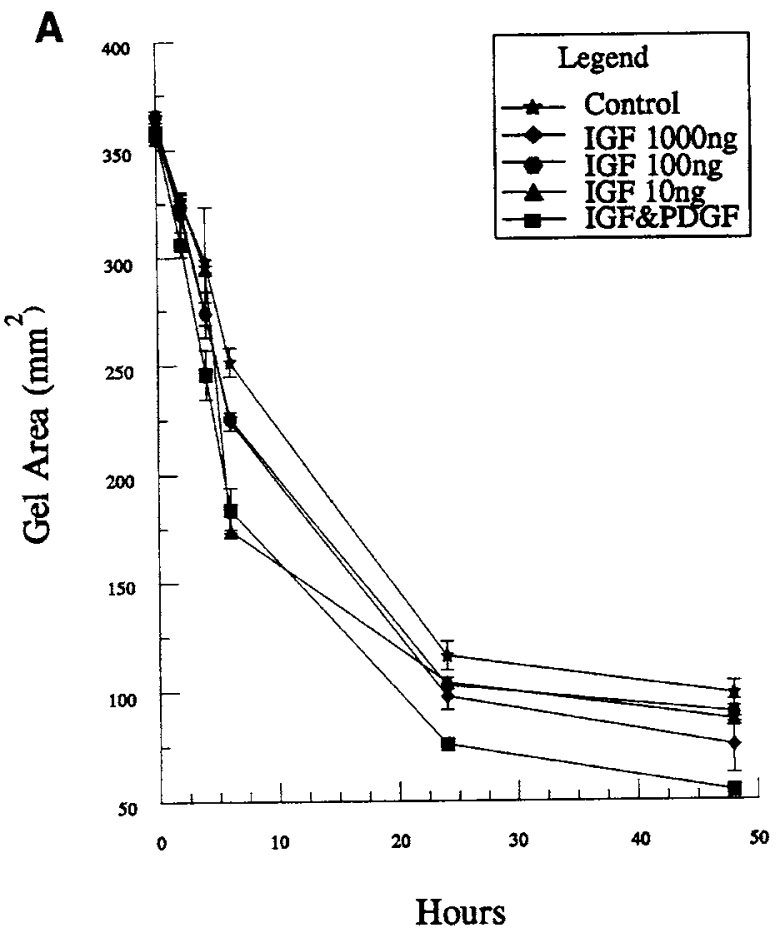

B

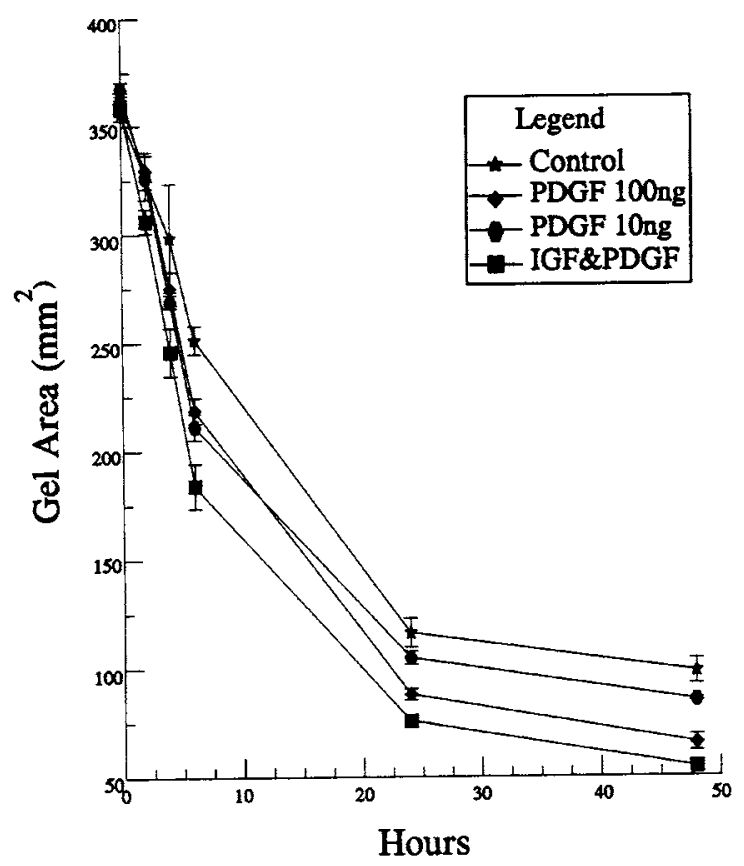

Figures 10A and 10B. Effects of IGF-1 and PDGF on cell-gel contraction. Gel contraction was significantly enhanced (P $\leq 0.01)$ at 4 hr by a combination of IGF-1 $1000 \mathrm{ng} / \mathrm{mL}$ (A) and PDGF $100 \mathrm{ng} / \mathrm{mL}$ (B). This stimulatory effect was most pronounced by $6 \mathrm{hr}$, when the IGF/PDGF combination showed a significantly $(\mathrm{P} \leq 0.001)$ greater contraction than other test groups and the control. This effect was sustained to $48 \mathrm{hr}$, when IGF/PDGF-treated gels demonstrated a statistically greater $(P \leq 0.001)$ contraction than all other groups except $P D G F-100 \mathrm{ng} / \mathrm{mL}(\mathrm{P} \geq 0.05)(\mathrm{n}=3)$.

combination had a slightly greater effect on contraction than either of these two agents alone. This combination was included since there is evidence that PDGF and IGF-1 together may have a synergistic effect on wound healing/periodontal regeneration (Lynch et al., 1991; Rutherford et al., 1993). This synergism is thought to be related to the position in the cell cycle at which these two cytokines influence cell proliferation, i.e., PDGF is thought to function as a progressive factor, while IGF acts as a competency factor (Lynch et al., 1991). However, it is unlikely that cell proliferation has a major influence on gel contraction in this model system, due to the relatively short time periods observed and the fact that cells in nonanchored gels have only limited proliferative activity (Grinnell, 1994). Thus, mechanisms other than those which increase cell mitogenesis may be operative. It has been demonstrated that collagen gel contraction is dependent on activation of cytoskeletal proteins (Bell et al., 1979; Tomasek et al., 1992), and that PDGF stimulates actin filament reorganization in monolayer cultures (Hammacher et al., 1989). PDGF also up-regulates expression of integrin collagen receptors $(\beta 1)$ in rat fibroblasts cultured in threedimensional gels (Gullberg et al., 1990). Furthermore, while IGF-1 has no known mitogenic effect on cells cultured in collagen (Gillery et al., 1992), its addition to cell-gel cultures enhances gel contraction, an effect possibly based on its ability to stimulate collagen gene expression and protein synthesis (Gillery et al., 1992). Collectively, these findings suggest that growth factors regulate wound healing, at least partially, via processes independent of cell proliferation.

The ability of PDGF and TGF- $\beta 1$ to promote cellmediated gel contraction at doses similar to those used in this study has been reported in previous studies where a variety of cell types was used (Montesano and Orci, 1988; Clark et al., 1989; Gullberg et al., 1990; Tingström et al., 1992). Several reports suggest that PDGF has a more rapid and pronounced effect on fibroblast-mediated gel contraction than TGF- $\beta$. Montesano and Orci (1988), using foreskin fibroblasts, found that gel contraction was delayed following the addition of TGF- $\beta$ (from 24 to $48 \mathrm{hrs}$ ) when compared with PDGF (approx. $2 \mathrm{hrs)}$ ) and proposed that TGF- $\beta$ may regulate gel contraction indirectly by stimulating endogenous production of PDGF. However, a more recent investigation (Tingström et al., 1992) reports that TGF- $\beta$ retains its stimulatory effect on gel contraction even when PDGF action is competitively blocked. In this present study, a delay in the effect of TGF- $\beta$ on gel contraction with use of gingival fibroblasts was not observed. Whether the differences in onset and rate of gel contraction in response to TGF- $\beta$ and PDGF are dependent on or affected by the specific cell type used is not known.

An unexpected finding was the observation that ethanol, even at very low concentrations $(\geq 1.0 \%$ or 217 $\mathrm{mM})$, had an inhibitory effect on fibroblast-mediated gel contraction. This finding was discovered when cell-gel controls were analyzed by means of the ethanol vehicle required to solubilize commercially prepared indomethacin and ibuprofen. Proliferation experiments 
demonstrated that gingival fibroblasts exposed to low concentrations of ethanol $(\geq 0.0004 \%)$ were growthinhibited up to five days in culture, whereafter only higher concentrations $(\geq 0.4 \%$ or $87 \mathrm{mM})$ continued to inhibit cell proliferation. Alcohol is known to have a dose-dependent effect on bone cells in vitro that is thought to be related to either the production of ethanol metabolites like acetaldehyde (Hurley et al., 1990) or the secondary induction of prostaglandins (Friday and Howard, 1991). In vitro concentrations of ethanol equivalent to serum levels achieved during social drinking (from 10 to $100 \mathrm{mM}$ ) have also been shown to have a strong inhibitory effect on cell adhesion molecule (CAM)-mediated cell-cell adhesion in human neural cels (Charness et al., 1994). Higher concentrations of alcohol $(200 \mathrm{mM})$ exert strong inhibitory effects on DNA synthesis in murine palate cells (Weston $e t$ al., 1994). It is currently unknown whether these cellular effects are responsible for the delayed wound-healing phenomenon observed in alcoholics. To the best of our knowledge, this is the first report of an adverse effect of alcohol on periodontal cells in vitro. Further investigations are necessary to determine the mechanisms involved and the clinical significance of this finding.

These results indicate that the cell-collagen gel contraction model holds promise as a useful tool for the study of matrix-related and cytoskeletal effects of woundhealing agents, especially those with potential utility in periodontal therapy. Importantly, because of the similarities between this in vitro system and contracting wound tissue, the fibroblast-contracted collagen lattice may represent a more tissue-equivalent construct than traditional monolayer cell cultures (Bell et al., 1979; Clark et al., 1989). However, caution must be used in interpretation of these results. Before a bioassay can be adopted as a true screening system, sources of inherent variation-including differences in cell response based on donor profile or period within culture (e.g., number of in vitro cell divisions) - must be first assessed. In addition, it should be recognized that an agent may inhibit cell-gel contraction in vitro and wound healing in vivo, but have a distinctly positive effect on another parameter, e.g., the positive effects of NSAIDs on bone remodeling in vivo may outweigh their possible negative effects on cell proliferation and cytoskeletal proteins. Furthermore, the doses of NSAIDs used to block proliferation and other cell activities in vitro in our studies and others (Nguyen and Lee, 1993) are approximately five times the peak serum levels measured in vivo. Determination of in vitro concentrations which are representative of "real" in vivo dosages is complicated by a number of problems, including a difficulty in calculating the proportion of free $v s$. protein-bound molecules in these two situations. Thus, in vitro data provide important information but must be carefully interpreted, and relevance to the in vivo situation must be established.

\section{Acknowledgments}

This study was funded by an Animal Alternatives Research
Program Grant from The Procter \& Gamble Co., Cincinnati, $\mathrm{OH}$. Ms. Hetty Pate processed the manuscript.

\section{References}

Aukhil I, Nishimura K, Fernyhough W (1990). Experimental regeneration of the periodontium. Crit Rev Oral Biol Med 1:101-115.

Bell E, Ivarsson B, Merrill C (1979). Production of a tissue-like structure by contraction of collagen lattices by human fibroblasts of different proliferative potential in vitro. Proc Natl Acad Sci USA 76:1274-1278.

Caffesse RG, Quinones CR (1993). Polypeptide growth factors and attachment proteins in periodontal wound healing and regeneration. I Periodontol 2000 1:69-79.

Charness ME, Safran RM, Perides G (1994). Ethanol inhibits neural cell-cell adhesion. I Biol Chem 269:9304-9309.

Clark RAF, Folkvord JM, Hart CE, Murray MJ, McPherson JM (1989). Platelet isoforms of platelet-derived growth factor stimulate fibroblasts to contract collagen matrices. J Clin Invest 84:1036-1040.

Ehrlich HP, White ME (1983). Effects of increased concentrations of prostaglandin $E$ levels with epidermolysis bullosa dystrophica recessive fibroblasts within a populated collagen lattice. J Invest Derm 81:572-575.

Friday KE, Howard GA (1991). Ethanol inhibits human bone cells proliferation and function in vitro. Metabolism 40:562-565.

Gillery P, Leperre A, Marquart F-X, Borel J-P (1992). Insulin-like growth factor-I (IGF-1) stimulates protein synthesis and collagen gene expression in monolayer and lattice cultures of fibroblasts. J Cell Physiol 152:389-396.

Grinnell F (1994). Fibroblasts, myofibroblasts, and wound contraction. J Cell Biol 124:401-404.

Gullberg D, Tingström A, Thuresson A-C, Olsson L, Terracio L, Borg TK, et al., (1990). $\beta_{1}$ integrin-mediated collagen gel contraction is stimulated by PDGF. Exp Cell Res 186:264-272.

Hammacher A, Mellström K, Heldin CH, Westermark B (1989). Isoform-specific induction of actin reorganization by platelet-derived growth factor suggests that the functionally active receptor is a dimer. EMBO J 8:2489-2495.

Heasman PA, Benn DK, Kelly PJ, Seymour RA, Aitken D (1993). The use of topical flurbiprofen as an adjunct to nonsurgical management of periodontal disease. J Clin Periodont 20:457-464.

Hoffman RM (1993). To do tissue culture in two or three dimensions? That is the question. Stem Cells 11:105-111.

Huang D, Chang TR, Agarwal A, Lee RC, Ehrlich HP (1993). Mechanisms and dynamics of mechanical strengthening in ligament-equivalent fibroblast-populated collagen matrices. Ann Biomed Eng 21:289-305.

Hurley MM, Martin DL, Kream BE, Raisz LG (1990). Effects of ethanol and acetaldehyde on collagen synthesis, prostaglandin release and resorption of fetal rat bone in organ culture. Bone 11:47-51.

Kasugai S, Ogura H (1993). The effects of cytoskeletal inhibitors on collagen gel contraction by dog periodontal ligament fibroblasts in vitro. Arch Oral Biol 38:785-792.

Kornman KS, Blodgett RF, Brunsvold M, Holt SC (1990). Effects of topical applications of meclofenamic acid and ibuprofen on bone loss, subgingival microbiota and gingival PMN response in the primate Macaca fascicularis. J Periodont Res 25:300-307. 
Lee T-L, Lin Y-C, Mochitate K, Grinnell F (1993). Stress-relaxation of fibroblasts in collagen matrices triggers ectocytosis of plasma membrane vesicles containing actin, annexins II and VI and $B_{1}$ integrin receptors. J Cell Sci 105:167-177.

Levi S, Goodlad RA, Lee CY, Stamp G, Walport MJ, Wright NA, et al. (1992). Non-steroidal anti-inflammatory drugs inhibit the processes of mucosal cell proliferation associated with duodenal ulcer healing. Digestion 53:129-133.

Lynch SE, Ruiz de Castilla G, Williams RC, Kiritsy CP, Howell TH, Reddy MS, et al.(1991). The effects of a short-term application of a combination of platelet-derived and insulin-like growth factors on periodontal wound healing. $J$ Periodontol 62:458-467.

MacNeil RL, Somerman MJ (1993). Molecular factors regulating development and regeneration of cementum. J Periodont Res 28:550-559.

McCulloch CAG (1993). Basic considerations in periodontal wound healing to achieve regeneration. J Periodont 2000 1:16-25.

Milam SB, Magnuson VL, Steffensen B, Chen D, Klebe RJ (1991). IL-1 $\beta$ and prostaglandins regulate integrin mRNA expression. J Cell Physiol 149:173-183.

Mochitate K, Pawelek P, Grinnell F (1991). Stress relaxation of contracted collagen gels: disruption of actin filament bundles, release of cell surface fibronectin, and down-regulation of DNA and protein synthesis. Exp Cell Res 193:198-207.

Montesano R, Orci L (1988). Transforming growth factor- $\beta$ stimulates collagen matrix contraction by fibroblasts: Implications for wound healing. Proc Natl Acad Sci USA 85:4894-4897.

Nakagawa S, Pawelek P, Grinnell F (1989). Extracellular matrix organization modulates fibroblast growth and growth factor responsiveness. Exp Cell Res 182:572-582.

Nguyen KD, Lee DA (1993). In vitro evaluation of antiproliferative potential of topical cyclooxygenase inhibitors in human Tenon's fibroblasts. Exp Eye Res 57:97-105.

Offenbacher S, Williams RC, Jeffcoat MK, Howell TH, Odle BM, Smith MA, et al.(1992). Effects of NSAIDs on beagle crevicular cyclooxygenase metabolites and periodontal bone loss. J Periodont Res 27:207-213.

Rutherford RB, Ryan ME, Kennedy JE, Tucker MM, Charette MF (1993). Platelet-derived growth factor and dexamethasone combined with a collagen matrix induce regeneration of the periodontium in monkeys. $J \mathrm{Clin}$ Periodontol 20:537-544.

Somerman MJ, Archer SY, Imm GR, Foster RA (1988). A comparative study of human periodontal ligament cells and gingival fibroblasts in vitro. J Dent Res 67:66-70.

Tingström A, Heldin C-H, Rubin K (1992). Regulation of fibroblast-mediated collagen gel contraction by plateletderived growth factor, interleukin- $1 \alpha$ and transforming growth factor- $\beta_{1}$. J Cell Sci 102:315-322.

Tomasek JJ, Haaksma CJ, Eddy RJ, Vaughan MB (1992). Fibroblast contraction occurs on release of tension in attached collagen lattices: dependency on an organized actin cytoskeleton and serum. Anat Rec 232:359-368.

Weston WM, Greene RM, Uberti M, Pisano MM (1994). Ethanol effects on embryonic craniofacial growth and development: Implications for study of the fetal alcohol syndrome. Alcohol Clin Exp Res 18:177-182. 